\title{
Survey on Distribution, Associated factors of Lumpy Skin Disease Occurrence and Its Vaccine Efficacy in selected Districts of East Wollega Zone, Western Oromiya
}

\author{
Zelalem Abera $^{1 *}$, Tadele Kabeta $^{1}$, Dereje Abera ${ }^{1}$ and Getachew Ayana ${ }^{2}$ \\ ${ }^{1}$ College of Medical and Health Sciences, School of Veterinary Medicine, Ethiopia \\ ${ }^{2}$ East Wollega Livestock and Fisheries Development and Resource office, Ethiopia
}

Received: 眥 January 03, 2019; Published: 眥 January 18, 2019

*Corresponding author: Zelalem Abera, Department of Veterinary Clinical Science and Lab. Technology, School of Veterinary Medicine, P.O. Box 395, Nekemte, Ethiopia

\begin{abstract}
Lumpy skin disease (LSD) is an economically devastating emerging viral disease of cattle caused by a virus associated with the Neethlig poxvirus in the genus Capripoxvirus of the family Poxviridae. The study was conducted to assess the factors that contribute the occurrence of lumpy skin disease and to determine the efficacy of its vaccine. This questionnaire survey assesses the status of LSD in two districts (Limmu and Leka Dulecha) of East Wollega Zone. Animal movement, Contact of animals, common grazing or watering points, Season, presence of wild life contact with the domestic animals, livestock marketing and vaccine efficacy were included in the study as variables. Eight (8) Peasant Associations (PAs) were randomly selected from the two (2) districts for the survey. Three hundred eighty $(\mathrm{n}=380)$ households were randomly selected to be interviewed. 195 (51.3\%) and 185 (48.7\%) of them were chosen from Limmu and Leka Dulecha districts, respectively. Majority of the respondents (97.4\%) were running mixed agriculture. Agro climatic condition of the area was observed and highland was the dominant one or $46.8 \%(\mathrm{P}=0.000$; $0 \mathrm{R}=2.92$; $\mathrm{CI}=1.16-7.33)$. Higher large herd size which exposes the animals for the disease was recorded as $70.5 \%(\mathrm{P}=0.004 ; \mathrm{OR}=8.47 ; \mathrm{CI}=1.12-64.06)$. Almost, all the selected households (99\% and 90.3\%) have the knowledge of LSD in Limmu and Leka Dulecha, respectively.

The result shows that $73.7 \%$ of respondents had vaccinated their cattle for the disease (P=0.018; OR=3.00; $\mathrm{CI}=1.21-7.44) .61 .6 \%$ of them were did not buy animals from open markets $(\mathrm{P}=0.01 ; \mathrm{OR}=12.8 ; \mathrm{CI}=1.70-96.8)$ which shows the ineffectiveness of the vaccine. $77.6 \%, 56.3 \%, 69.7 \%$ and 93.7\% of herd owners were reported the absence of animals contact with different areas, PAs, district and Zones or regions, respectively. As $99.5 \%$ of the respondents reported, there was no seasonal movement of animals from place to place for search of feed and water. Even though, $73.8 \%$ and $73.5 \%$ participants are practicing vaccination of animals in Limmu and Leka Dulecha, the disease is occurring in the areas. As analysis indicated, $82.7 \%$ of the respondents of Leka Dulecha district were replied as the vaccine was not effective against $\mathrm{LSD}(\mathrm{P}=0.006 ; \mathrm{OR}=8.05 ; \mathrm{CI}=1.84-35.21)$. Result of the finding provides preliminary information on the factors associated for the occurrence of LSD infection in Limmu and Leka Dulecha districts. Some of the risk factors like seasons, herd size, vaccination, introducing new animals into the herds were found to be associated with the occurrence of disease. Detail study on the transmission of the disease, vaccine efficacy and teaching the community with the basic knowledge of risk factors is warranted.
\end{abstract}

Keywords: Cattle; Efficacy; Ethiopia; Leka Dulecha; Limmu; LSD; Risk factors; Vaccine

Abbreviations: LSD: Lumpy Skin Disease; PAs: Peasant Associations; GDP: Gross Domestic Product; EMDTI: Ethiopian Meat and Dairy Technology Institute

\section{Introduction}

\section{Background}

Livestock production constitutes one of the principal means of achieving improved living standards in many regions of the developing world [1-3]. The livestock sector globally is highly dynamic, contributes $40 \%$ of the global value of agricultural output, and support the livelihoods and food security of almost a billion people [4]. In many developing countries (In Sub-Saharan African countries), livestock keeping is a multifunctional activity and plays a crucial role both in national economies and the livelihood of rural communities. Beyond their direct role in generating food 
and income, livestock are a valuable asset, serving as a store of wealth, provides drought power, clothing, transport and serve as a source of manure for energy and soil fertility, collateral for credit and an essential safety net during times of crisis [1,3]. In Ethiopia, Livestock production is an integral part of the agricultural system. The livestock sub sector accounts for $40 \%$ of the agricultural gross domestic product (GDP) and 20\% of the total GDP without considering other contribution like traction power, fertilizing and mean of transport [5-6]. The livestock sector is now has significant contribution to the total foreigner currency of the country.

In the future, livestock production will increasingly be affected by competition for natural resources, particularly land and water, competition between food and feed and by the need to operate in a carbon-constrained economy [7]. Currently the overall livestock production constraints in Ethiopia are feed shortages, livestock diseases, low genetic potential of indigenous livestock, and lack of marketing infrastructure and water shortages [8-10]. Among the many other diseases, which are known in causing economic losses and of poor productivity in livestock specifically in cattle is the presence of lumpy skin disease in many parts of the country [11-13]. Lumpy skin disease (LSD) is a generalized skin disease which is an infectious, eruptive, occasionally fatal disease of cattle caused by a virus associated with the neethlig poxvirus in the genus Capripoxvirus of the family Poxviridae [14-17]. The economic losses due to this disease is associated with decreased milk production, traction power loss, weight loss, poor growth, abortion, infertility and skin damage. Pneumonia is a common sequel in animals with lesions in the mouth and respiratory tract [18-23].

LSD was first observed in the western part of Ethiopia (southwest of Lake Tana) in 1983 [24]. It has now spread to almost all the regions and agro ecological zones [10,25]. Some epidemiological studies have been carried out since the disease has become established in the country, with the diverse agro-ecological and production systems [10]. Study based on sero-prevalence in southern Ethiopia reported a prevalence of 6\% [26]. Targeted sampling from outbreak areas around Southern Range land, Wolliso town and north Ethiopia reported prevalence's of $11.6 \%$, $27.9 \%$ and $28 \%$, respectively [26,27-28]. A recent prevalence study [13] results showed higher herd prevalence recorded in Afar (51\%) and Tigray (37\%) regions. Published information on the factors that influence the occurrence of LSD are not many as general, however some studies indicated that LSD is a disease which affect all age group, in Africa imported Bos Taurus appear to be more susceptible than the indigenous breeds [18]. The LDSV was found to be associated with Capri poxvirus outbreaks in Kenya [29]. A clinical case of LSD has been reported in other animals: Asian water buffalo from Egypt [30].

Antibodies have been demonstrated in black and blue wild beests, Elan, Giraffe, greater Kudu and others [31,32]. Some researchers have made attempt the transmission of the disease with different flies [14,33-35]. Recently, [36] reported the potential role of ixodic tick in the transmission of LSDV. Weather changes such as cold may adversely affect the insect vector and infected saliva may contribute to the spread of the disease [37]. Lumpy skin disease is one of the taransboundry diseases which cause economic loss in livestock industry. Hence, the study area interfaces with Benishangul Gumuz Regional State of Ethiopia and other neighbouring African countries (Sudan and South Sudan). However, there is no preliminary information about the disease in East Wollega zone except few informal outbreak reports from the area. Thus, it needs to assess its magnitude, the factors those contribute to the occurrence of the disease in the study areas and to determine the efficacy of its vaccine.

\section{Material and Methods \\ Description of Study Areas}

The study was conducted in two (2) randomly selected districts (Limu and Leka Dulecha) of East Wollega Zone, Oromiya regional state of Ethiopia. Nekemte is the capital city of the zone which is found at $331 \mathrm{~km}$ of west of Addis, the capital city of Ethiopia [38]. Agriculture is the main livelihood in which cattle and sheep are kept as the major livestock. The rearing system of cattle in study sites depends on natural grass and crop residues that kept in traditional management system [39]. Leka Dulecha is one of the districts of Eastern Wollega Zone. It's part of the East Wollega Zone and it was part of former Diga Leka district. The 2007 national census reported a total population for this district of 72,057 , of whom 35,479 were men and 36,578 were women; 4,056 or $5.63 \%$ of its population are urban dwellers.

The majority of the inhabitants observed Protestantism, with $44.3 \%$ reporting that as their religion, while $43.15 \%$ observed Ethiopian Orthodox Christianity, and 8.58\% were Muslim. Limmu is one of the second largest districts in the East Wollega Zone. It is bordered by the Benishangul-Gumuz Region on the northwest on the south by Guto Wayu, on the west by Limmu, by Ibantu, on the north, and on the east by Horo Gudru Wollega Zone. Gelila is the administrative centre. This district is characterized by undulating hills north of Dicho Ridge and by plains south of it; it was once covered by extensive forests, but as of 2005 only a few fragments remain. The majority of the inhabitants were Ethiopian Orthodox Christianity, with $59.33 \%$ of the population reporting they observed this belief, while $23.4 \%$ of the population said they were Protestant, and $16.17 \%$ were Moslem [40].

\section{Study Design and Population}

A cross-sectional study was conducted to assess the distribution, risk factors and vaccine efficacy of LSD occurrence in the study area. Random sampling method was followed to select two (2) districts and eight (8) PAs to be included in the study in consultation with the respective district Livestock and Fisheries Development and Resource office experts. Households of the randomly selected PAs were the sampling units for questionnaire survey.

\section{Sampling Technique and Sample Size Determination}

The random sampling technique was followed, to select households to be used for the survey. Minimum sample size for this study was calculated using the formula by [41] with $95 \%$ confidence level and 5\% absolute precision. The sample size was achieved by assuming the risk factors associated with observed clinical lumpy skin disease in Ethiopia which was 55.2\% [11]. 


$$
\frac{n=1.96^{2} * P \exp (1-P \exp )}{d^{2}}
$$

Where: $\mathrm{n}$ = required sample size; exp = expected prevalence; $\mathrm{d}$ $=$ desired absolute precision.

Therefore, $\mathrm{n}=(1.96) 2 * 0.552 *(0.448)=380(0.05) 2$

Accordingly, 380 desired sample sizes for the study was calculated.

\section{Questionnaire Survey}

Questionnaire was administered to a total of 380 households. Face to face interview using local language (Afan Oromo) which took 10-15 minutes was conducted. Twenty (20) major questions were designed to capture the necessary information. The contents of the questionnaire survey like socio-demographic data and history of diseases occurrence (common constraints of livestock, major livestock diseases, season of occurrence and duration of outbreak) were included. Additionally, information based on herd management (Herd size, herd structure, introduction of new animal, vaccination status, watering or grazing points, contact of animals with different areas and wild life, presence of disease transmission, Biting flies \& existence of livestock markets), breed and sex were collected. The selected farmers then were asked questions related to the above concept. Additionally, they were asked to explain the symptoms of the disease. Clinical observations of sick animals

\section{Results}

\section{Study Participants Based on their Districts and Peasant Associations}

Table 1: Study participants based on their districts.

\begin{tabular}{|c|c|c|c|c|c|}
\hline Districts & $\begin{array}{c}\text { Numbers of } \\
\text { respondents }\end{array}$ & Percentage (\%) & P-value & OR & 95\%CI \\
\hline Limmu & 195 & 51.3 & 0.002 & - & $2.38-45.49$ \\
\hline Leka Dulecha & 185 & 48.7 & - & - \\
\hline Total & 380 & 100.00 & & \\
\hline
\end{tabular}

Note: NB: OR= Odds Ratio; $\mathrm{CI}=$ Confidence Interval.

Table 2: Address (Peasant Associations) of Study Participants in the Study Areas.

\begin{tabular}{|c|c|c|c|}
\hline Districts & Peasant Associations of respondents & Numbers of respondents & Percentage (\%) \\
\hline \multirow{4}{*}{ Limmu } & Lemiti & 53 & 13.9 \\
\hline & Dibisa Biya & 47 & 12.4 \\
\hline & Saketa Kiltu Babo & 44 & 11.6 \\
\hline & Mukarba Dima & 51 & 13.4 \\
\hline Sub-total & 4 & 195 & 51.3 \\
\hline \multirow{4}{*}{ Leka Dulecha } & Digga Fododo & 46 & 12.1 \\
\hline & Migna Kersa & 51 & 13.4 \\
\hline & Jarso Liya & 44 & 11.6 \\
\hline & Jarso Gute & 44 & 11.6 \\
\hline Sub-total & 4 & 185 & 48.7 \\
\hline Total & 8 & 380 & 100 \\
\hline
\end{tabular}

Cite this article: Zelalem A, Tadele K, Dereje A, Getachew A. Survey on Distribution, Associated factors of Lumpy Skin Disease Occurrence and Its Vaccine Efficacy in selected Districts of East Wollega Zone, Western Oromiya. Biomed J Sci \& Tech Res 13(2)-2019. BJSTR. MS.ID.002385. DOI: 10.26717 / BJSTR.2019.13.002385. 
Table 3: Common constraints of the livestock production system in the study areas.

\begin{tabular}{|c|c|c|c|c|}
\hline Districts & Diseases (\%) & Disease and feed shortage (\%) & Disease, Water and feed shortage (\%) & Total (\%) \\
\hline Limmu & $38(19.5)$ & $86(44.1)$ & $71(36.4)$ & $195(51.3)$ \\
\hline Leka Dulecha & $59(31.9)$ & $36(19.5)$ & $90(48.6)$ & $185(48.7)$ \\
\hline Total & $97(25.5)$ & $122(32.1)$ & $161(42.4)$ & $380(100.00)$ \\
\hline
\end{tabular}

During this study period, a total of $380(n=380)$ households were selected from two districts (Limmu and Leka Dulecha) of the Zone and interviewed. The study was significantly higher $(\mathrm{P}<0.05$, $\mathrm{OR}=10.4, \mathrm{CI}=2.38-45.49$ ) in Limmu district as compared to Leka
Dulecha district (Table 1). Eight (8) Peasant Associations (PAs) were randomly selected from two (2) districts and the households were also randomly selected from each PAs to be interviewed (Tables 2 \& 3).

\section{Demographic Characteristics of the Respondents}

Table 4: Socio-Demographic Characteristics of the Respondents in the Study Areas.

\begin{tabular}{|c|c|c|c|c|c|c|c|}
\hline \multirow{2}{*}{$\begin{array}{l}\text { Socio- demographic } \\
\text { characteristic }\end{array}$} & \multirow{2}{*}{ Categories } & \multicolumn{2}{|c|}{ Districts } & \multirow{2}{*}{ Frequency (\%) } & \multirow{2}{*}{ P-value } & \multirow{2}{*}{ OR } & \multirow{2}{*}{$95 \% \mathrm{CI}$} \\
\hline & & Limmu (\%) & L/Dulecha (\%) & & & & \\
\hline \multirow[t]{2}{*}{ Sex } & Males & $152(77.9)$ & $168(90.8)$ & $320(84.2)$ & 0.92 & 0.9 & $0.27-03.31$ \\
\hline & Females & $43(22.1)$ & $17(9.2)$ & $60(15.8)$ & - & - & - \\
\hline \multirow[t]{2}{*}{ Age } & Young (15-30) & $84(43.1)$ & $7(3.8)$ & $91(23.9)$ & 0.34 & 1.8 & $0.53-6.40$ \\
\hline & Adults $(>30)$ & $111(56.9)$ & $178(96.2)$ & $289(76.1)$ & - & - & - \\
\hline \multirow[t]{2}{*}{ Education } & Literate & $145(73.4)$ & $135(73)$ & $280(73.7)$ & & & \\
\hline & Illiterate & $50(25.6)$ & $50(27)$ & $100(26.3)$ & & & \\
\hline \multirow{3}{*}{ Livelihood (Occupation) } & Livestock's only & - & $4(2.2)$ & $4(1.1)$ & - & - & - \\
\hline & $\begin{array}{c}\text { Mixed } \\
\text { Agriculture }\end{array}$ & $195(100)$ & $175(94.6)$ & $370(97.4)$ & 0.24 & 3.7 & $0.41-33.2$ \\
\hline & Trading only & - & $6(3.2)$ & $6(1.6)$ & - & - & - \\
\hline \multirow[t]{3}{*}{ Agro climate of the area } & Highland & 56 (28.7) & 122 (65.9) & $178(46.8)$ & $\begin{array}{c}0.000 \\
*\end{array}$ & 2.9 & $1.16-7.33$ \\
\hline & Midland & $112(57.4)$ & $63(34.1)$ & $175(46.1)$ & - & - & - \\
\hline & Lowland & $27(13.8)$ & - & 27 (7.1) & - & - & - \\
\hline Total & & 195 (51.3) & 185 (48.7) & $380(100)$ & & & \\
\hline
\end{tabular}

Note: NB: * = Statistically significant.

Other socio-demographic characteristics of study participants like sex, age, educational status and livelihood (occupation) were included in the study. Generally, majority of them were males (84.2\%), individuals greater than thirty years (76.1\%), literate (73.7\%) and respondents those running their livelihood with mixed agriculture (97.4\%) were included (Table 4). Highland was the dominant agro climatic condition (46.8\%) and showed statistically significant difference $(\mathrm{P}=0.000 ; \mathrm{OR}=2.92 ; \mathrm{CI}=1.16-7.33)$ in this study.

Table 5: Herd Level Information of Animals in both Districts.

\section{Herd Level Information of Animals}

Majority of the respondents were reported that $88.2 \%$ and $78.9 \%$ of the herds were local breed in Limmu and Leka Dulecha distracts, respectively. The analysis revealed that $85.3 \%$ of the herd involves all structures (Ox, Bull, Beef, Lactating cow, Dry cow, Heifer, Calf) in both districts. But, as the respondents informed, $70.5 \%$ large herd size was recorded in the study areas and the herd size was statistically significant $(\mathrm{P}=0.004 ; \mathrm{OR}=8.47 ; \mathrm{CI}=1.12-64.06)$ (Table 5).

\begin{tabular}{|c|c|c|c|c|c|c|c|}
\hline \multirow{2}{*}{ Parameters } & \multirow{2}{*}{ Categories } & \multicolumn{2}{|c|}{ Districts } & \multirow{2}{*}{ Frequency (\%) } & \multirow{2}{*}{ P-value } & \multirow{2}{*}{ OR } & \multirow{2}{*}{$95 \% \mathrm{CI}$} \\
\hline & & Limmu (\%) & L/Dulecha (\%) & & & & \\
\hline \multirow[t]{2}{*}{ Breed } & Local & $172(88.2)$ & $146(78.9)$ & 318 (83.7) & - & - & - \\
\hline & Cross & $23(11.8)$ & 39 (20.1) & $62(16.3)$ & - & - & - \\
\hline \multirow[t]{2}{*}{ Herd size } & Small & $104(53.3)$ & $8(4.3)$ & $112(29.5)$ & $0.04^{*}$ & 8.47 & $1.12-64.06$ \\
\hline & Large & $91(46.7)$ & 177 (95.7) & $268(70.5)$ & - & - & - \\
\hline \multirow[t]{2}{*}{ Herd structure } & Almost all & $170(87.2)$ & 154 (83.2) & 324 (85.3) & 0.24 & 0.29 & $0.04-2.22$ \\
\hline & $0 x$ & 25 (12.8) & $31(16.8)$ & $56(14.7)$ & - & - & - \\
\hline Total & & $195(51.3)$ & 185 (48.7) & $380(100.00)$ & & & \\
\hline
\end{tabular}

Note: NB: L/Dulecha = Leka Dulecha; ${ }^{*}=$ Statistically Significant.

Cite this article: Zelalem A, Tadele K, Dereje A, Getachew A. Survey on Distribution, Associated factors of Lumpy Skin Disease Occurrence and Its Vaccine Efficacy in selected Districts of East Wollega Zone, Western Oromiya. Biomed J Sci \& Tech Res 13(2)-2019. BJSTR. MS.ID.002385. DOI: 10.26717/ BJSTR.2019.13.002385. 


\section{Common Constraints of Livestock Production System in the Study Areas}

Major constraints were disease and feed shortage, diseases, water and feed shortage in livestock production system in both districts (Limmu and Leka Dulecha) were identified during this study period. Relatively majority of the constraints were reported by respondents from Leka Dulecha district (48.6\%) as compared with Limmu district (36.4\%) Diseases, water and feed shortage (42.4\%) were the main constraints of livestock production identified in the study areas (Table 3).

\section{Associated Risk Factors of Lumpy Skin Disease Occurrence}

Majority of respondents (94.7\%) have knowledge of LSD in both districts. $73.7 \%$ of respondents were replied that, their cattle had been vaccinated for the disease and vaccination was statistically significant $(\mathrm{P}=0.018 ; \mathrm{OR}=3.00 ; \mathrm{CI}=1.21-7.44)$. And also $61.6 \%$ of them were informed as they did not buy animals from open markets. However, buying new cattle from the market showed statistically significant association $(\mathrm{P}=0.01 ; \mathrm{OR}=12.8 ; \mathrm{CI}=1.70$ 96.8). The result showed that $46.6 \%$ interviewers were informed as they are introducing new cattle to their herds. 92.6\% respondents were practicing communal watering and grazing points with other herds in the areas (Table 6). As the result indicated that, 77.6\%, $56.3 \%, 69.7 \%$ and $93.7 \%$ of herd owners were reported the absence of animals contact with different areas, PAs, district and Zones or regions, respectively. As $99.5 \%$ of the respondents reported, there was no seasonal movement of animals from place to place for search of feed and water; that means most of the farming system in the area was sedentary.

Majority of the herd owners (94.5\%) were didn't know any disease that can be transmitted from wild life to domestic animals and about $84.2 \%$ of them were assured the existence of livestock marketing place in the study areas (Table 5). In both districts, $45 \%$ of study participants are practicing vaccination of their animals at winter season of the year in which it was higher in Leka Dulecha $(60.5 \%)$ and $43.2 \%$ of them are using both (Communal and Separate) grazing type in the areas. But, communal grazing type was statistically significant $(\mathrm{p}=0.00 ; \mathrm{OR}=2.0 ; \mathrm{CI}=5.58-6.94)$. As $67.1 \%$ of the study participants said, animals contact each other in summer season of the year, but it was higher in Limmu district (79\%). A proportion of $91.8 \%$ respondents were agreed as livestock marketing place can be way of disease transmission (Table 6). The result revealed that summer was the season at which an activity of biting flies high (41.3\%).

Table 6: Summary of Major risk factors for the Occurrence of LSD in the study areas.

\begin{tabular}{|c|c|c|c|c|c|c|c|c|}
\hline \multirow{3}{*}{$\begin{array}{c}\text { Major Risk Factors for } \\
\text { LSD }\end{array}$} & \multicolumn{4}{|c|}{ Districts } & \multirow{2}{*}{\multicolumn{2}{|c|}{$\begin{array}{l}\text { Total Number of } \\
\text { respondent (\%) }\end{array}$}} & \multirow{2}{*}{\multicolumn{2}{|c|}{ P-value OR 95\% CI }} \\
\hline & \multicolumn{2}{|c|}{ Limmu } & \multicolumn{2}{|c|}{ Leka Dulecha } & & & & \\
\hline & Yes (\%) & No $(\%)$ & Yes (\%) & No $(\%)$ & Yes (\%) & No (\%) & & \\
\hline Do you know LSD & $193(99)$ & $2(1)$ & $167(90.3)$ & $18(9.7)$ & $360(94.7)$ & $20(5.3)$ & 0.3414 .4 & $0.53-6.40$ \\
\hline $\begin{array}{c}\text { Have vaccinated your } \\
\text { animals? }\end{array}$ & $144(73.8)$ & $51(26.2)$ & $136(73.5)$ & $49(26.5)$ & $280(73.7)$ & $100(26.3)$ & $0.018 * 3.00$ & $1.21-7.44$ \\
\hline Did you buy new cattle & $121(62.1)$ & $74(37.9)$ & $25(13.5)$ & $160(86.5)$ & $146(38.4)$ & $234(61.6)$ & $0.01 * 12.8$ & $1.70-96.8$ \\
\hline $\begin{array}{l}\text { An introduction of new } \\
\text { cattle }\end{array}$ & $120(61.5)$ & $75(38.5)$ & $57(30.8)$ & $128(69.2)$ & $177(46.6)$ & $203(53.4)$ & 0.750 .87 & $0.35-2.13$ \\
\hline $\begin{array}{l}\text { Do you have common } \\
\text { grazing or }\end{array}$ & $179(91.8)$ & $16(8.2)$ & $173(93.5)$ & $12(6.5)$ & $352(92.6)$ & $28(7.4)$ & 0.560 .4 & $0.51-0.61$ \\
\hline \multicolumn{9}{|c|}{ Watering Points with other Herds } \\
\hline $\begin{array}{c}\text { Contact with animals of } \\
\text { different }\end{array}$ & $180(92.3)$ & $15(7.7)$ & $115(62.2)$ & $70(37.8)$ & 295 (77.6) & $85(22.4)$ & 0.090 .17 & $0.02-1.31$ \\
\hline \multicolumn{9}{|c|}{ area } \\
\hline $\begin{array}{c}\text { Contact of animals with } \\
\text { different }\end{array}$ & $94(48.2)$ & 101 (51.8) & $72(38.9)$ & $113(61.1)$ & 166 (43.7) & $214(56.3)$ & 0.7331 .17 & $0.47-2.94$ \\
\hline \multicolumn{9}{|c|}{ PAs } \\
\hline $\begin{array}{c}\text { Contact of animals with } \\
\text { different }\end{array}$ & $54(27.7)$ & $141(72.3)$ & $61(33)$ & $124(67)$ & 115 (30.3) & 265 (69.7) & 0.981 .01 & $0.38-2.71$ \\
\hline \multicolumn{9}{|c|}{ District } \\
\hline $\begin{array}{l}\text { Contact with different } \\
\text { Zone or }\end{array}$ & $24(12.3)$ & 171 (87.7) & - & $185(100)$ & $24(6.3)$ & 356 (93.7) & 1.0024 .3 & $0.99-1.00$ \\
\hline \multicolumn{9}{|c|}{ Regions } \\
\hline $\begin{array}{l}\text { Did you move your cattle } \\
\text { to other }\end{array}$ & $2(1)$ & 193 (99) & - & $185(100)$ & $2(0.5)$ & 378 (99.5) & 0.501 .9 & $0.45-0.55$ \\
\hline \multicolumn{9}{|c|}{ Grazing Place Seasonally } \\
\hline $\begin{array}{c}\text { Do you know any disease } \\
\text { that can }\end{array}$ & $9(4.6)$ & $186(95.4)$ & $12(6.5)$ & $173(93.5)$ & $21(5.5)$ & 359 (94.5) & 0.0000 .04 & $0.02-0.12$ \\
\hline
\end{tabular}

Cite this article: Zelalem A, Tadele K, Dereje A, Getachew A. Survey on Distribution, Associated factors of Lumpy Skin Disease Occurrence and Its Vaccine Efficacy in selected Districts of East Wollega Zone, Western Oromiya. Biomed J Sci \& Tech Res 13(2)-2019. BJSTR. MS.ID.002385. 


\begin{tabular}{|c|c|c|c|c|c|c|c|c|}
\hline \multicolumn{9}{|c|}{ be Transmitted from Wild Life to } \\
\hline \multicolumn{9}{|c|}{ livestock } \\
\hline $\begin{array}{c}\text { Existence of livestock } \\
\text { marketing }\end{array}$ & $168(86.2)$ & $27(13.8)$ & $152(82.2)$ & $33(17.8)$ & $320(84.2)$ & $60(15.8)$ & 0.311 .3 & $0.26-0.35$ \\
\hline $\begin{array}{c}\text { NB: }{ }^{*}=\text { Statistically } \\
\text { significant }\end{array}$ & & & & & & & & \\
\hline
\end{tabular}

Effectiveness of the Lumpy Skin Disease Vaccine: Majority of the study participants (54.7\%) were confirmed that LSD vaccine was not effective against the disease. About $82.7 \%$ of the respondents of Leka Dulecha district were replied as the vaccine was not effective against the disease. This was higher as compared with Limmu district (28.2\%). However, $54.7 \%$ of the study participants were replied as the vaccine was not effective, vaccine efficacy showed statistically significant association $(\mathrm{P}=0.006$; $\mathrm{OR}=8.05$; $\mathrm{CI}=1.84$ 35.21) (Table 7).

Table 7: Summary of Major risk factors for the Occurrence of LSD Based on Seasons.

\begin{tabular}{|c|c|c|c|c|c|c|c|c|}
\hline \multirow{2}{*}{$\begin{array}{l}\text { Major Risk Factors for } \\
\text { LSD Occurrence }\end{array}$} & \multirow[b]{2}{*}{ Categories } & \multicolumn{2}{|c|}{ Districts } & \multirow{2}{*}{$\begin{array}{l}\text { Frequency } \\
(\%)\end{array}$} & \multirow[b]{2}{*}{$P$-value } & \multirow[b]{2}{*}{ OR } & \multicolumn{2}{|c|}{$95 \% \mathrm{CI}$} \\
\hline & & Limmu (\%) & $\begin{array}{c}\text { Leka Dulecha } \\
\text { (\%) }\end{array}$ & & & & Lower & Upper \\
\hline \multirow{4}{*}{$\begin{array}{l}\text { At which season you } \\
\text { vaccinate your animals? }\end{array}$} & Winter & $59(30.3)$ & $112(60.5)$ & $171(45.0)$ & 0.03 & 0.09 & 0.01 & 0.8 \\
\hline & Summer & 23 (11.8) & $43(23.2)$ & $66(17.4)$ & 0.06 & 0.14 & 0.02 & 1.07 \\
\hline & Autumn & $34(17.4)$ & $1(0.5)$ & $35(9.2)$ & 0.13 & 0.15 & 0.01 & 1.76 \\
\hline & Spring & $79(40.5)$ & 29 (15.7) & $108(28.4)$ & - & - & - & - \\
\hline \multirow[t]{3}{*}{ Grazing type } & Separate & $12(6.2)$ & $67(36.2)$ & $79(20.8)$ & - & - & - & - \\
\hline & Communal & $108(55.4)$ & 29 (15.7) & $137(36.1)$ & 0 & 2 & 5.58 & 6.94 \\
\hline & Both & 75 (38.5) & $89(48.1)$ & $164(43.2)$ & - & - & - & - \\
\hline \multirow[t]{4}{*}{ Seasons of animals contact } & Summer & 154 (79) & $101(54.6)$ & $255(67.1)$ & 0.41 & 2.15 & 0.35 & 13.12 \\
\hline & Winter & $12(6.2)$ & - & $12(3.2)$ & 0.32 & 0.28 & 0.02 & 3.38 \\
\hline & Autumn & $5(2.6)$ & $28(15.1)$ & $33(8.7)$ & 0 & 0.04 & 0.01 & 0.17 \\
\hline & Spring & $24(12.3)$ & $56(30.3)$ & $80(21.1)$ & - & - & - & - \\
\hline \multirow{6}{*}{$\begin{array}{l}\text { Season at activity of biting } \\
\text { flies high }\end{array}$} & Summer & $83(42.6)$ & $74(40)$ & $157(41.3)$ & 0.09 & 7.65 & 0.72 & 81.46 \\
\hline & Winter & $39(20)$ & 27 (14.6) & $66(17.4)$ & 0.25 & 4.2 & 0.37 & 48.16 \\
\hline & Autumn & $30(15.4)$ & $48(25.9)$ & $78(20.5)$ & 0.79 & 1.36 & 0.14 & 12.87 \\
\hline & Spring & 34 (17.4) & 36 (19.5) & $70(18.4)$ & 0.14 & 6.8 & 0.52 & 88.54 \\
\hline & $\begin{array}{l}\text { Winter \& } \\
\text { Spring }\end{array}$ & $3(1.5)$ & $3(1.6)$ & $6(1.6)$ & - & - & - & - \\
\hline & $\begin{array}{l}\text { Autumn \& } \\
\text { Spring }\end{array}$ & $6(3.1)$ & - & $6(1.6)$ & & & & \\
\hline \multirow{2}{*}{$\begin{array}{l}\text { Livestock marketing place } \\
\text { can be way of disease } \\
\text { transmission }\end{array}$} & Agree & $172(88.2)$ & 177 (95.7) & 349 (91.8) & 0.92 & 0.94 & 0.27 & 3.31 \\
\hline & Disagree & $23(11.8)$ & $8(4.3)$ & $31(8.2)$ & - & - & - & - \\
\hline \multirow[t]{2}{*}{ Effectiveness of the vaccine } & Effective & $140(71.8)$ & $32(17.3)$ & $172(45.3)$ & - & - & - & - \\
\hline & Not effective & $55(28.2)$ & $153(82.7)$ & $208(54.7)$ & $0.006^{*}$ & 8.05 & 1.84 & 35.21 \\
\hline
\end{tabular}

\section{Discussion}

In the present study, questionnaire survey was under taken to identify major risk factors that contribute to the occurrence of Lumpy Skin Disease (LSD) and to determine the efficacy of its vaccine in two administrative districts of East-Wollega Zone (Limmu and Leka Dulecha). During this study period, a total of 380 $(\mathrm{n}=380)$ respondents (Households) were randomly selected from 8 Peasant Associations (PAs) of two (2) districts and they were interviewed. Relatively higher respondents were participated from Limmu (51.3\%) than form Leka Dulecha district (48.7) and the study was significantly higher $(\mathrm{P}=0.02, \mathrm{OR}=10.4, \mathrm{CI}=2.38-45.49)$ in Limmu as compared to Leka Dulecha district (Table 1). Different risk factors that contribute to the occurrence of lumpy skin disease were identified. This has been reported $[30,42]$ that the outbreak of the disease was mostly associated with the prevalence of insect vectors, host susceptibility, livestock density at the grazing and watering points, husbandry systems, wet seasons and agro ecologic conditions, presence of moist, humidity, market conditions and an introduction of new animals without any examination.

Relatively higher respondents were recorded in Lemiti (13.9\%) and Migna Kersa peasant associations (13.4\%) of Limu and Leka Dulecha districts, respectively. Based on their sex and age, $84.2 \%$ of them were males while $15.8 \%$ of them were females and $76.1 \%$ of them were adults ( $>30$ years) while $23.9 \%$ of them were 
young (15-30 years). According to their educational status, the respondents were classified as literate; $73.7 \%$ while about $26.3 \%$ illiterate. Additionally, based on their livelihood (Occupation); $1.1 \%, 97.4 \%$ and $1.6 \%$ of them were practicing Livestock's only, mixed agriculture and trading, respectively. The study areas were classified in to three agro climate has highland (46.8\%), midland (46.1\%) and lowland (7.1\%). This agrees with the report of [10] who reported majority of the respondents $(93.3 \%, 80.2 \%, 81.3 \%$, 83.3\%, 73.8\%) were Christian, literate, males, adult and practicing mixed agriculture, respectively in Gimbi and Lalo Assabi districts of West Wollega zone.

Major constraints commonly encountered in livestock production system in both districts (Limu and Leka Dulecha) were identified during this study period. These main problems or constraints of livestock in the area were diseases, disease and feed shortage, disease, water and feed shortage. Disease and feed shortage was the highest constraint identified in Limu district (44.1\%) but, disease, water and feed shortage was the highest constraint in Leka Dulecha district (48.6\%). The result of this finding is in line with the report of $[10,43-44]$ who stated that diseases were the main constraints of livestock. Some other constraints observed in both districts were lack of veterinary extension services and poor breeds. So, the findings of the major constraints limiting livestock production during the present study in the area was tended to agree with findings found [43]. As the questionnaire survey result indicated Lumpy Skin Disease (LSD) was dominates the area due to one or more factors those attributes the occurrence of the disease. From the result, $94.7 \%$ of respondents in both districts were informed presence of the disease (LSD) in their areas.

This agrees well with the finding of [11], in which about $42.8 \%$ of the interviewees reported occurrence of LSD in their herd and [10] who reported about $65.1 \%$ of the respondents were knew the disease in their areas. However, vaccination is widely prescribed as an effective control measure for Lumpy Skin Disease (OIE 2010); little is known on the immunological response and immune dynamics against this disease. During this study, about $73.7 \%$ of respondents were informed as their cattle had been vaccinated for the disease (LSD), but $54.7 \%$ of the study participants complained on the efficacy of the vaccine against the disease in both districts. About $82.7 \%$ of the respondents of Leka Dulecha district were replied as the vaccine was not effective against Lumpy Skin Disease. This was higher as compared with Limmu district (28.2\%) Strongly they informed that, the vaccine has no potential to develop immunity and protect the animals from the disease. This was due to continuous occurrence of the disease even after vaccination in the areas. Veterinary professionals were also asked for the reason of poor efficacy of the vaccine and they have shared what the farmers have said, but the vaccine might develop immunity after booster vaccination.

But, the result offinding conducted by [45] at Bishoftu Agriculture Research Centre and Ethiopian Meat and Dairy Technology Institute (EMDTI) on towards effective vaccine production showed as the vaccinated animals were able to produce antibodies before day 7 of post vaccination. Additionally, some literatures have indicated that vaccinated animals produce neutralizing antibodies before day 7 of post vaccination [46]. As result of the study showed, about $46.6 \%$ respondents were informed as they are introducing new cattle to their safe herds without identifying whether the animal was vaccinated or not. This indicated that, most herd owners from both districts acquired cattle through purchasing from auction markets and very few of them claimed that they acquired cattle from inheritance or dowry. Similar finding was reported by [10], as the frequency of introduction of new animals was higher in the midland agro-climate zone $(40.6 \%)$ than in the highland and the lowland zones $(25.2 \%$ and $21 \%$, respectively). The same authors also reported that the introduction of new animals to a herd had a strong association with an increased risk of disease in the herd and a noticeable proportion of farmers (32.1\%) reported introducing new animals to their herd following purchase (for replacement, herd expansion, fattening), receiving cultural gifts or cattle exchange without any screening for the health status of the new animal. However, it was not statistically significant $(p>0.05$ ) for the occurrence of the disease in the area.

During this study, higher proportions of respondents (92.6\%) have reported as they are practicing communal watering and grazing points with other herds in both districts. Even though there was an increment report found with communal grazing and watering points, multivariate logistic regression analysis revealed statistically insignificant effect among these risk factors and occurrence of the disease in the area. However, [10] mentioned that communal grazing and watering points were found to be associated with the occurrence of LSD. But communal grazing type (36.1\%) was statistically significant ( $p>0.000,0 R=2.0, \quad C I=5.58-6.94)$. Additionally, different authors [33,47-48] were reported as sharing watering points, grazing plots and post-harvest fields would allow contact and intermingling of different herds that would probably increase the risk of exposure. As the result indicated that, $77.6 \%$, $56.3 \%, 69.7 \%$ and $93.7 \%$ of herd owners were reported the absence of animals contact with different areas, PAs, district and Zones or regions, respectively. This could be due to animal's movement from place to place for the purpose of vaccination, trade activity, searching for feed and water during dry season and other activities, which is a risk factor in contracting cattle diseases such LSD. The result of this finding agrees with the report of [10].

An $84.2 \%$ of respondents were declared, as there was existence of livestock marketing in the area. This is another opportunity for the occurrence of contagious and infectious diseases including LSD. About $91.8 \%$ of them were agreed as this livestock marketing place can be way of disease transmission among animals in the study areas. As $99.5 \%$ of the respondents were reported, there was no seasonal movement of animals from place to place for search of feed and water; that means most of the farming system in the area was sedentary. This is supported by the result of [10] in which $68.3 \%$ (172) herd owners have informed the absence of seasonal movement of animal. Result of this finding indicated that, most of the herd owners (94.5\%) had no information about the disease that can be transmitted from wild life to domestic animals and about $84.2 \%$ of them were assured the existence of livestock marketing place in the study areas. It is in line with the finding of [49], who 
reported the actual number of LSDV-infected wild ruminants may be considerably higher than that revealed by this test. Wild animals showing clinical signs of LSD are likely to be more susceptible to predators, which could explain the lack of reports of clinical disease in wildlife species.

In addition, the presence of clinical signs of LSD in wildlife is easily missed. The seasons were also compared and about $67.1 \%$ of the study participants were said, animals contact each other in summer season of the year in which it was higher in Limmu district (79\%). The result revealed that summer was the season at which an activity of biting flies high (41.3\%). The result of this finding is in agreement with the report of [10] about $67.1 \%$ of respondents reported that, a summer (wet season) was a season at which the activity of biting flies is high. Flies activity was four times (4x) more likely to be high in the summer (wet) as compared to other seasons for the occurrence of the disease in the area. Similar to this finding, [42,11] mentioned, LSD outbreaks were associated with wet and warm weather conditions due to an abundance of blood-feeding arthropod populations in the summer season [50] also mentioned that, epidemics of LSD are associated with rainy seasons. Additionally, [51] reported the occurrence of the disease at the herd level during the rainy season which might be due to the increment of the vector population.

\section{Conclusion and Recommendations}

The questionnaire survey result indicated that Lumpy Skin Disease (LSD) is an important disease in Limmu and Leka Dulecha districts. It was aimed to assess magnitude of LSD, the factors those contribute to its occurrence and to determine efficacy of LSD vaccine in the study areas. Sex, age, educational status and livelihoods were observed. Some of the risk factors such as Agro climatic condition, herd size, practicing vaccination of animals, LSD vaccine efficacy, buying cattle from the open markets were found to be associated in this study. Also, cattle management practices executed by livestock owners of the study area, namely: introduction of new animal to the herd, mixing of cattle in watering and grazing areas, free movement of animals to different areas and others are very common in the areas. These can be risk factors and could aggravate the spread of lumpy skin disease in the study areas. The result also indicated as the vaccine has no efficacy. So, the finding provides preliminary information on the factors associated for the occurrence of LSD infection in Limmu and Leka Dulecha districts.

It also gives attention on the distribution of the disease in the areas and can assist planners, decision-makers, practitioners and researchers in their efforts. In addition, it could help them in disease surveillance and control activities for risk mitigation and to improve the health of animals. Finally, LSD Vaccine production should be qualified and/or examined at its production table, mass vaccination should be applied for all cattle in both districts using an effective specific vaccine against LSD (Attenuated Neethling strain vaccine). The use of insecticides to control biting flies before raining season should be practiced, livestock owner need to be aware with the basic knowledge of risk factors those contribute to disease (Limiting movement of animals, communal watering and grazing points, etc) and due to the biggest challenge, that was poor infrastructure that facing during this study, further research is needed to assess the status of the disease and to suggest implementation of appropriate control and prevention methods in the areas.

\section{Compliance with Ethical Standards}

The research was conducted in accordance with the ethical standards of Wollega University; Research and Technology Transfer (approval number WU/RD/27/07).

\section{Acknowledgement}

We are very much grateful to the Wollega University for the research fund and all staff of Wollega University, School of Veterinary Medicine who assisted us, including moral support, in one way or another during our study period. Also we are greatly in debated to Limmu and Leka Dulecha Livestock and Fisheries Development and Resource office especially veterinary clinic workers, for their valuable advice, encouragements, provision of materials and co-operation in different aspects during our work. Finally, our thanks have to reach all of our friends and others for their all sided support.

\section{References}

1. ILCA (1980) International Livestock Centre for Africa. Economic Trends; Livestock Production Prospects for Tropical Africa in the Year 2000. ILCA Bulletin No. 10. ILCA, Addis Ababa, Ethiopia.

2. MoA (2006) Ministry of Agriculture and Rural Development, the Status of Animal Health Services in Ethiopia. Addis Ababa, Ethiopia.

3. (2009) FAO, Livestock in balance. Food and Agriculture Organization of the United Nations, Vialedelleterme di Caracalla, Rome, Italy.

4. Thornton PK (2010) Livestock production: recent trends, future prospects. The Royal Society, 365(1554): 2853-2867.

5. Aklilu Y, Irungu P, Alemayehu R (2003) An Audit of the Livestock Marketing Status in Kenya, Ethiopia and Sudan. In Issues and Proposed Measures, II. Community Based Animal Health and Participatory Epidemiology Unit. Nairobi: Pan African Programme for the Control of Epizootics, African Union/Interafrican Bureau for Animal Resources.

6. Gebreegziabhare B (2010) An over view of the role of Ethiopian livestock in livel hood and Food safety. Ministry of Agriculture and Rural development of Ethiopia; Presente on dialogue 10 on livestock, food security and sustainability, a side event on the session of 22nd COAGO, FAO, Rome.

7. Thornton PK (2006) Mapping climate vulnerability and poverty in Africa. Nairobi, Kenya, ILRI.

8. Markos Tibbo (1999) Livestock Production Constraints in a M2-2 SubAgro ecological Zone with Special Reference to Goat Production. Sheno Agricultural Research Centre, Debre Berhan, Ethiopia.

9. Alemayehu M (2009) Country pasture/forage profiles.

10.Zelalem Abera, Hailu Degefu and Getachew Gari (2015) Assessment of Distribution and Associated Risk Factors of Lumpy Skin Disease in Selected Districts of West Wollega Zone, Western Ethiopia. Academic Journal of Animal Diseases 4(3): 130-140.

11. Gari G, Waret Szkuta A, Grosbois V, Jacquiet P, Roger F (2010) Risk factors associated with observed clinical lumpy skin disease in Ethiopia. Epidemiol. Infection 138(11): 1657-1666.

12. Gari G, Grosbois V, Waret Szkuta A, Babiuk S, Jacquiet P, et al. (2012) Lumpy skin disease in Ethiopia: Seroprevalence study across different agro-climate zones. Acta Tropica 123(2): 101-106. 
13. Birhanu H, Getachew G, Tadele T, Belay B, Teshale T (2015) Study on the Epidemiological and Financial Impacts of Clinical Lumpy Skin Disease in Selected Districts of Tigray and Afar Regional States, North Eastern Ethiopia. International Journal of Current Research 7(6): 17415-17425.

14. Chihota CM, Rennie LF, Kitching RP, Mello PS (2003) Attempted mechanical transmission of lumpy skin disease virus by biting insects. Medical and Veterinary Entomology 17(3): 294-300.

15. Stram Y, Kuznetzova L, Rubinstein Guni M, Fridgut O, Yadin H (2006) The recent Lumpy Skin Disease outbreak in Israel, A molecular prospect. Israel Journal of Veterinary Medicine.

16. Ahmed WM, Zaher KS (2008) Observations on lumpy skin disease in local Egyptian cows with emphasis on its impact on ovarian function. African Journal Microbiology Res 2(10): 252-257.

17. Gari G, Bonnet P, Roger F, Waret Szkuta A (2011) Epidemiological Aspects and Financial Impact of Lumpy Skin Disease in Ethiopia. (NAHDIC), Prevention and Veterinary Medicine 102(4): 274-283.

18. Davies FG (1991) Lumpy skin disease of cattle: A growing problem in Africa and the Near East Veterinary Research Laboratories, Kabete, Kenya.

19. Kassa B, Bisrat M, Asegedech S, Africa J (1998) Control of "Ekeke" Skin Defects in Sheep by Insecticides and Shearing. EVA Proceeding $12^{\text {th }}$ Annual Conference. Addis Ababa, Ethiopia, pp. 104-109.

20. Mc Dermott J, Randolph T, Staal S (1999) The economics of optimal health and productivity in smallholder livestock systems in developing countries. Rev Science and Technology Office of International Epizootics 18(2): 399-424.

21. Yacob H, Nesanet B, Dinka A (2008) Part II: Prevalence of major skin diseases in cattle, sheep and goats at Adama Veterinary Clinic, Oromia regional state, Ethiopia. Revue Medicine. Veterinary 159(8-9): 455-461.

22. Ocaido M, Otim CP, Kakaire D (2009) Impact of major diseases and vectors in smallholder cattle production systems in different agroecological zones and farming systems 11 in Uganda. FVM, Makerere University, Kampala, Uganda. Livestock Research for Rural Development 21(9).

23. OIE, (2010) Lumpy skin disease. In manual of diagnostic tests and vaccines for terrestrial animals. Office International des Epizooties, World Organization for Animal Health, Paris, p. 1-13.

24. Mebratu GY, Kassa B, Fikre Y, Bethany B (1984) Observations on the outbreak of lumpy skin disease in Ethiopia. La Revue d'Elevage et de Médecine Vétérinaire des Pays Tropicaux, 37(4): 395-399.

25. Babiuk S, Bowden TR, Dalman B, Parkyn G, Copps J (2008) Quantification of lumpy skin disease virus following experimental infection in cattle. Transboundary and Emerging Diseases 55(7): 299-307.

26. Gari G, Biteau Coroller F, Le Goff C, Caufour P, Roger F (2008) Evaluation of Indirect Fluorescent Antibody Test (IFAT) for the Diagnosis and Screening of Lumpy Skin Disease Using Bayesian Method. Veterinary Microbiology 129(3-4): 269-280.

27. Asegid B (1991) Epidemiological Study of Major Skin Diseases of Cattle in Southern Range Lands. DVM Thesis, FVM, AAU, Bishoftu, Ethiopia.

28. Beshahwured S (1991) Outbreak of Lumpy Skin Disease in and around Wolliso. Faculty of Veterinary Medicine, Addis Ababa University, Bishoftu, Ethiopia.

29. Kitching RP, Bhat PP, Black DN (1989) The characterization of African strains of Capri poxviruses. Epidemiology and Infection 102(2): 335343.

30. Ali AA, Esmat M, Attia H, Selim AY, Abdelhamid M (1990) Clinical and pathological studies on lumpy skin disease in Egypt. Veterinary. Rec 127(22): 549-550.

31. Hedger RS, Hamblin C (1983) Neutralizing antibodies to lumpy skin disease virus in African wildlife. Comp. Immunology and Microbiology 6(3): 209-213.
32. Barnard B, Munz E, Dumbell K, Prozesky L (1994) Lumpy Skin Disease. Oxford University Press Oxford.

33. Chihota CM, Rennie LF, Kitching RP, Mellor PS (2001) Mechanical transmission of lumpy skin disease virus by Aedesaegypti (Diptera. Culicidae). Epidemiology Infection 126(2): 317-321.

34. Carn VM, Kitching RP (1995b) An investigation of possible routes of transmission of lumpy skin disease (Neethling) virus. Epidemiology of Infection 114(1): 219-226.

35. Carn VM (1996) The role of dipterous insects in the mechanical transmission of animal viruses. British Veterinary Journal 152(4): 377393.

36. Tuppurainen ES, Stoltsz WH, Troskie M, Wallace DB, Oura CA, et al. (2011) A potential role for ixodid (Hard) tick vectors in the transmission of lumpy skin disease virus in cattle. Transbound Emerging Diseases, 58(2): 90-104.

37. Haig DA (1957) Lumpy skin disease. Bulletin of Epizootics Disease Africa 5: 421-430.

38. Mekuria S, Gadissa F (2011) Survey on bovine trypanosomosis and its vector in Metekel and Awi zones of Northwest Ethiopia. Acta Tropica 117(2): 146-151.

39. (2010) CSA, Central Statistical Agency. Statistical abstracts; Agriculture and climate, CSA, Addis Ababa, Ethiopia.

40. (2012) PHCE, Population and Housing Census of Ethiopia: Results for Oromiya Region 1.

41. Thrusfield M (2007) Veterinary epidemiology. ( $3^{\text {rd }}$ edn.), Blackwell Science, Cornwall, UK.

42. Tuppurainen ESM, Oura CALB (2012) Review: Lumpy Skin Disease: An Emerging Threat to Europe, the Middle East and Asia. Tran boundary and Emerging Diseases 59(1): 40-48.

43. Nibret M, Basaznew B (2012) Assessment of Major Animal Production and Health Problems of Livestock Development in Lay-Armacheho District, North-western Ethiopia Department of Veterinary Clinical Studies, FVM, University of Gondar, Gondar, Ethiopia. American-Eurasian Journal of Scientific Research 7(3): 136-141.

44. Belay Duguma, Yisehak Kechero, Geert PJ Janssens (2012) Survey of Major Diseases Affecting Dairy Cattle in Jimma Town, Department of Animal Science, Jimma University, Oromia, Ethiopia: Global Veterinaria, $8(1): 62-66$.

45. Tilahun Z, Berecha B, Simenew K, Reta D (2014) Towards Effective Vaccine Production: A Controlled Field Trial on the Immunological Response of Three Lumpy Skin Disease Vaccine Strains in Dairy Farms. Academic Journal of Animal Diseases 3(3): 17-26.

46. Kithing RP, Hammond JM (1992) Poxvirus infection and immunity ( $3^{\text {rd }}$ edn.), In Encyclopaedia of immunology (Roitt IM, Delves PJ (Eds.). Academic press, London 3(3): 1261-1264.

47. Kitching R, Taylor P (1986) Insect transmission of Capri poxviruses. Research in Veterinary Science, 40(2): 255-258.

48. Waret Szkuta A, Ortiz Pelaez A, Roger F, Pfeiffer DU, Guitian FJ (2010) Herd contact structure based on shared use of water points and grazing points in the Highlands of Ethiopia. Epidemiology Infection, in press 139(6): 875-885.

49. Barnard BJH (1997) Antibodies against some viruses of domestic animals in South African wild animals. Onderstepoort Journal. Veterinary Res 64: 95-110.

50. Troyo A, Calderon Arguedas O, Fuller DO, Solano ME, Avendano A, et al. (2008) Seasonal profiles of Aedes aegypti (Diptera: Culicidae) Larval habitats in an urban area of Costa Rica with the history of mosquito control. Journ of Vector Ecology 33(1): 1-13.

51. Zelalem A, Hailu D, Getachew G, Menbere K (2015) Sero-prevalence of lumpy skin disease in selected districts of West Wollega zone, Ethiopia. BMC Veterinary Research 11: 135. 


\section{ISSN: 2574-1241}

DOI: $10.26717 / B J S T R .2019 .13 .002385$

Zelalem Abera. Biomed J Sci \& Tech Res

(C) (i) This work is licensed under Creative

Submission Link: https://biomedres.us/submit-manuscript.php

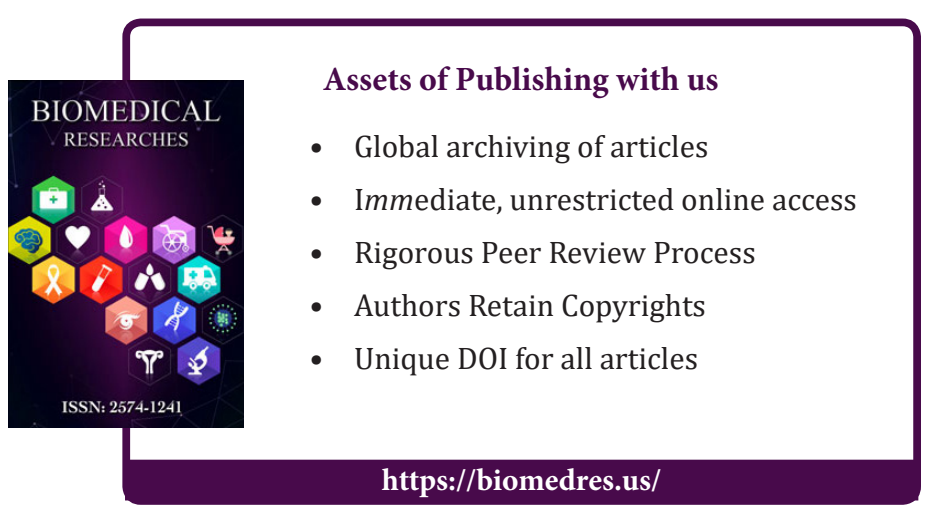

